\title{
Economics
}

HEI Working Paper No: 06/2004

\section{Wage-Price Dynamics and Deflation in Hong Kong}

\author{
Hans Genberg \\ Graduate Institute of International Studies \\ Laurent L. Pauwels \\ Graduate Institute of International Studies
}

\begin{abstract}
This paper provides empirical evidence on the dynamics of prices and wages in Hong Kong. The results imply that the deflation in Hong Kong since 1997 can be understood using a conventional macroeconomic framework wherein foreign influences constitute the basic underlying shocks, and adjustment processes in domestic wages and prices determine the details of the transmission mechanism. Our results indicate that the decline in local nominal prices owes much to declining prices of imported intermediate goods. The negative output gap and the increase in unemployment experienced during the deflation period also have their origin in foreign shocks, but the domestic wage adjustment process constitutes an important contributing factor.
\end{abstract}

(C) The Authors.

All rights reserved. No part of this paper may be reproduced without the permission of the authors. 
Wage-Price Dynamics and Deflation in Hong Kong

\author{
Hans Genberg* \\ Laurent Pauwels*
}

This Version: August 2004

\begin{abstract}
This paper provides empirical evidence on the dynamics of prices and wages in Hong Kong. The results imply that the deflation in Hong Kong since 1997 can be understood using a conventional macroeconomic framework wherein foreign influences constitute the basic underlying shocks, and adjustment processes in domestic wages and prices determine the details of the transmission mechanism. Our results indicate that the decline in local nominal prices owes much to declining prices of imported intermediate goods. The negative output gap and the increase in unemployment experienced during the deflation period also have their origin in foreign shocks, but the domestic wage adjustment process constitutes an important contributing factor.

JEL classification: E31, F41, N15, C51

Paper prepared for the CEPR/HIEBS/HKIMR Conference on 'Deflation, Pegs and Capital Flows', 1/2 December 2003, Hong Kong. Comments from our Guy Meredith, our discussant, other participants at the conference as well as an anonymous referee are gratefully acknowledged. The paper was prepared in part within the NCCR Finrisk project "Macro Risk, Systemic Risk and International Finance". The NCCR is a research program supported by the Swiss National Science Foundation.

*Graduate Institute of International Studies, 132 rue de Lausanne, 1211 Geneva 21, Switzerland. Email: genberg@hei.unige.ch and pauwels0@hei.unige.ch
\end{abstract}




\section{Introduction.}

During the six years ending in 2003 the consumer price index in Hong Kong fell by 15 percent. During the same period the unemployment rate increased to $8.7 \%$ in the third quarter of 2003 from $2.1 \%$ in the third quarter of 1997 . By any definition this must be what we mean by deflation. In this paper we attempt to explain the main features of the deflation process by estimating and interpreting a set of equation describing the interrelationships between domestic inflation, wage changes, the output gap, unemployment, and their mutual dependence on foreign economic conditions. Our purpose is to see whether the deflation can be explained by a standard macroeconomic approach involving foreign and domestic shocks together with a conventional propagation mechanism. We conclude that the deflation process in Hong Kong can indeed be understood in these terms where the main sources of shocks are of foreign origin, and where the propagation mechanism involves somewhat sluggish wage adjustments. We also find evidence suggestive of changes in the propagation mechanism in the post-1997 period.

The remainder of the paper is organized as follows. In the next section we present some stylized facts about the recent deflationary period, including the evolution of domestic and foreign price and business cycle indicators. These stylized facts suggest a prima-facie case for a dominant role of external shocks in the deflation process. This hypothesis is tested in subsequent sections. In section III we use Granger-causality tests and a semi-structural vector autoregression model to document the importance of external price and output shocks for the evolution of prices, wages and unemployment in Hong Kong. We also find, however, that domestic factors are important in the short to medium run, especially for wages and unemployment. Section IV provides a structural interpretation of these findings. A brief concluding section ends the paper.

\section{The Nature of the Current Deflation in Hong Kong.}

The current deflation began in 1997/98. Measured by the implicit GDP deflator the price level peaked in the $4^{\text {th }}$ quarter of 1997, and the consumer price index started falling three quarters later. From their respective peaks the indices have fallen by $23 \%$ and $17 \%$ respectively (Figure II.1).

Other important indicators of nominal prices and costs have evolved in a similar manner. For example, the property price index fell from a value of 104 at its peak in the $3^{\text {rd }}$ quarter of 1997 to 35.5 in 2003:2. While nominal wages have not fallen during the price deflation, their growth rate has declined from an annual rate of about $7 \%$ during the five years before the start of the deflation to essentially zero since (Figure II.2). ${ }^{1}$

Prices of goods imported into Hong Kong and a weighted average of consumer prices in Hong Kong's main trading partners have also followed generally downward

\footnotetext{
${ }^{1}$ From 1992:4 until 1997:4 nominal wages rose by $36.9 \%$, and from 1997:4 to 2003:1 the growth rate was $-.1 \%$.
} 
paths in recent years, but the start of their decline happened earlier. The unit value of imports peaked two years before the domestic GDP deflator, and has fallen by some 19\% since then. The weighted average of trading partners CPIs (expressed in terms of HKD) stopped rising in the middle of 1995, fell close to $10 \%$ during the following three years before recovering and again reaching the 1995 level in the middle of 2003. (Figure II.3).

These developments should be interpreted against the background of the currency-board arrangement in place in Hong Kong which implies a virtual peg of the HKD to the USD at the rate of $7.8 \mathrm{HKD} / \mathrm{USD} .{ }^{2}$ Together with the highly open nature of the economy, the fixed exchange rate implies that external events should play an important role for domestic price movements. Indeed one of the hypotheses we will investigate is the extent to which the current price deflation is completely externally determined. An alternative possibility is that external developments constitute the principal fundamental shocks, but that domestic factors have an important role in the propagation mechanism of these external shocks. We will also investigate a third hypothesis which has frequently been articulated namely that the property price decline, the start of which precedes the decline in the general price level, is an important independent cause of the deflation.

Deflation would be relatively innocuous if it simply meant declining nominal variables and if employment and output were unaffected. The problem of course is that such a neat dichotomy may not be present. In Hong Kong, the evolution of indicators of real economic activity suggests that there might be some reason for concern. The unemployment rate has been rising at a seemingly accelerating rate from its trough in 1990 of about $1 \%$ of the labor force to around 3\% in 1996 to close to $9 \%$ in mid- 2003 . (Figure II.4) At the same time output growth has been slowing steadily from the 5-6\% range in the late 1980 s to the $2-3 \%$ range in the past five years. Cyclical indicators show sharp declines in economic activity in the immediate aftermath of the South-East Asian Crisis and again in 2001-2. The extent to which the price deflation in the past six years has contributed to the slowing down of real economic activity will be investigate later in the paper. Here we simply note that at least the cyclical swings in the Hong Kong economy follow quite closely, but with higher amplitude than those in the main trading partners. (Figure II.5)

\footnotetext{
${ }^{2}$ The value 7.8 represents a ceiling for the exchange rate and formally there is no floor. However, the fluctuations have been minimal from the point of view of pass-through of foreign price changes. The lowest value of the Hong Kong dollar during the past 10 years is less than one percentage point from the maximum.
} 

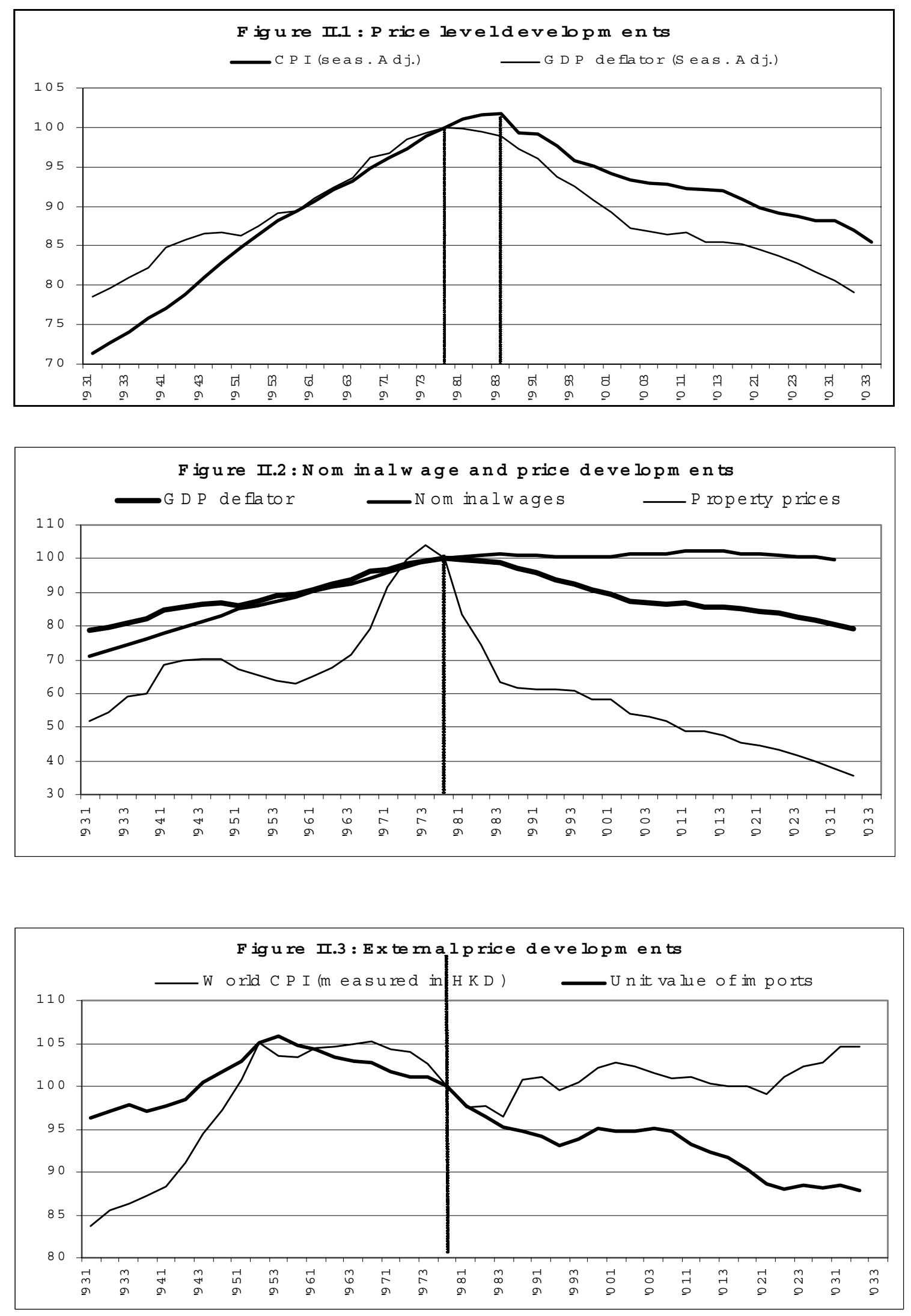

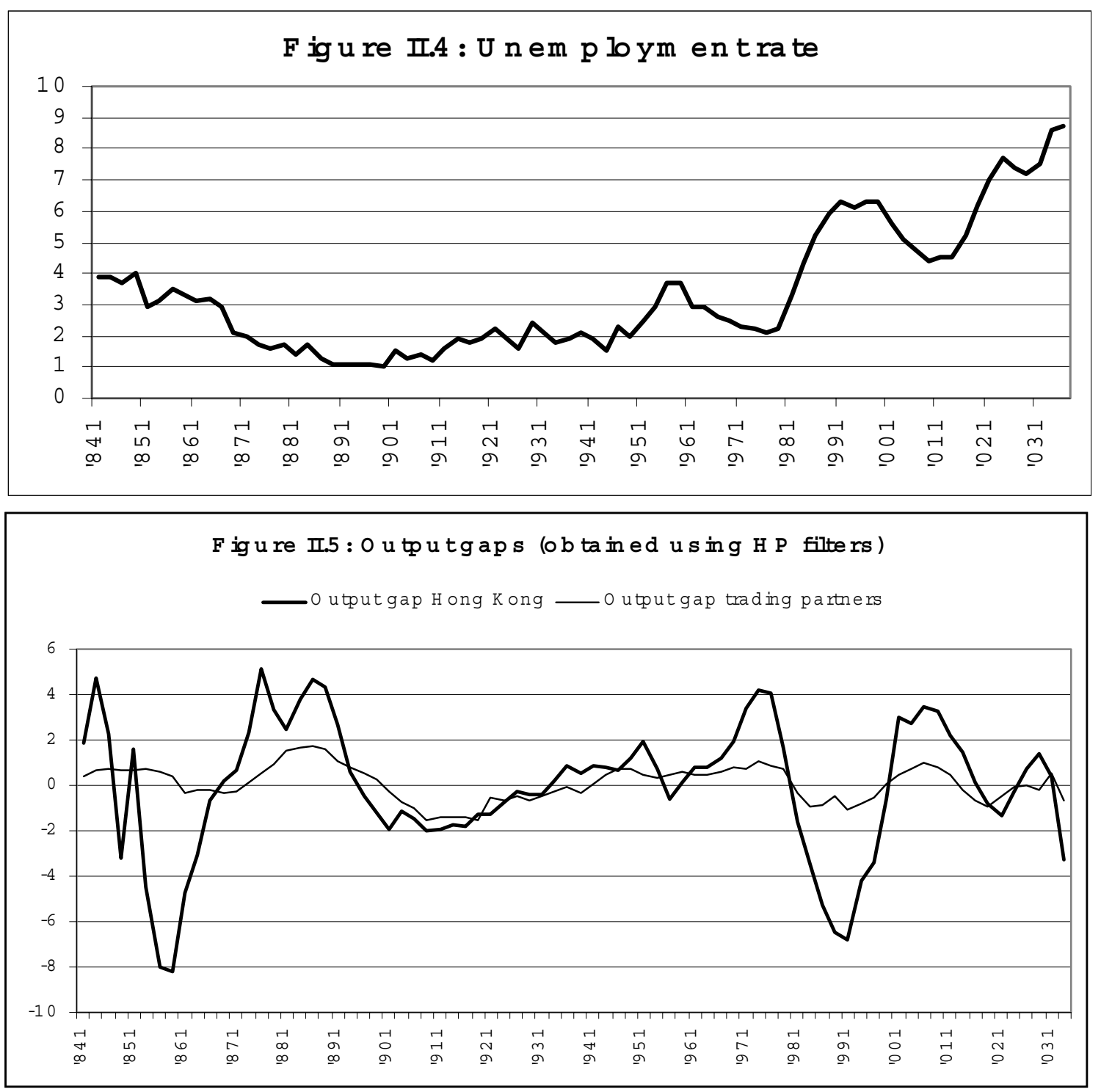

\section{Inflation dynamics: causality tests and evidence from semi-structural models.}

In this section we show that a description of inflation dynamics in Hong Kong requires first and foremost careful attention to international influences in the form of world price, interest rate and output movements, reflecting external cost and demand factors. But our evidence also indicates that a full understanding of the short- to mediumterm dynamics of domestic prices requires taking account of the interaction between prices, wages and economic activity in the Hong Kong economy. Finally we argue that property price developments do not appear to have had an important independent role in the inflation process, but have instead reacted endogenously to the external influences that also drive inflation more generally. 
III.1 Granger-causality tests.

Genberg and Pauwels (2003) [hereafter GP] present extensive evidence from Granger-causality tests and bivariate vector autoregressions (VAR) between domestic prices (both the CPI and the GDP deflator), domestic nominal wages, property prices and several measures of international prices (CPI in the United States, a weighted average of CPIs in Hong Kong's main trading partners, and import prices). For our purposes here, the results in that paper can be summarized in three points. First, even though the Hong Kong dollar is fixed in relation to the US dollar, price developments in the United States do not have a particularly strong influence on Hong Kong prices and wages. Second, a weighted average of consumer prices in HK's main trading partners and a measure of HK import prices do have strong influences on both the local consumer price index and the GDP deflator. Import prices influence local wages and property prices as well. Third, there is a mutual interdependence between HK wages and the GDP deflator.

The Granger-causality tests in GP (2003a) were based mainly on bivariate regressions. This opens up the possibility that the relationships found are the consequence of common effects of third variables. To investigate this possibility we conduct block exogeneity test in a VAR system that includes four domestic variables (the GDP deflator, nominal wage rates, the nominal property prices, and the unemployment rate) and three foreign variables (the US three-month T-Bill rate, unit value of Hong Kong imports, and a measure of the output gap in Hong Kong's main trading partners). We estimate the VAR system both in levels and in quarterly rates of change. ${ }^{3}$ The results are presented in Table III.1. For each of the four domestic variables we conducted tests for the exclusion of the lags of the exogenous variables. Only those variables whose lags are significant at the $10 \%$ level or lower are shown in the table.

The results confirm and extend those found in GP (2003a). First, foreign factors have significant effects on each of the four domestic variables included in the system. Lagged import prices have significant effects on both the GDP deflator and nominal wages. They also influence the unemployment rate in the level specification. The US interest rate has an impact on the GDP deflator in the level specification and on property price inflation in the growth rate specification, and the external output gap influences the domestic unemployment rate in the system estimated in growth rates. Second, the interaction between domestic variables remains after we control for the effects of foreign variables. The exact nature of the interaction depends on whether we consider the level or growth rate specifications, but some patterns can be discerned ${ }^{4}$ (i) the GDP deflator influences and is influenced by nominal wages, (ii) the unemployment rate has an impact on wages, and (iii) wages influence the unemployment rate.

\footnotetext{
${ }^{3}$ In each case the unemployment rate, the T-Bill rate, and the foreign output gap are measured in percentages.

${ }^{4}$ The significance level of the interaction terms between the domestic variables is also affected by the lag length in the VARs. The importance of foreign variables, however, is robust.
} 


\begin{tabular}{|c|c|c|}
\hline \multicolumn{3}{|c|}{ Table III.1: Granger-causality tests } \\
\hline Log-levels $^{1}$ & \multicolumn{2}{|c|}{ p-values of a test for the exclusion of 2 lags of } \\
\hline GDP deflator & $\begin{array}{l}\text { Nominal wages } \\
\text { Import prices } \\
\text { US 3-M T-Bill rate }\end{array}$ & $\begin{array}{l}0.09 \\
0.00 \\
0.06\end{array}$ \\
\hline Nominal wages & $\begin{array}{l}\text { Unemployment rate } \\
\text { Import prices }\end{array}$ & $\begin{array}{l}0.06 \\
0.01\end{array}$ \\
\hline Nominal property prices & GDP deflator & 0.03 \\
\hline Unemployment rate & Import prices & 0.10 \\
\hline Quarterly rates of change $^{2}$ & \multicolumn{2}{|c|}{ p-values of a test for the exclusion of 4 lags of } \\
\hline GDP deflator & Import prices & .01 \\
\hline Nominal wages & $\begin{array}{l}\text { GDP deflator } \\
\text { Unemployment rate } \\
\text { Import prices }\end{array}$ & $\begin{array}{l}0.01 \\
0.10 \\
0.02\end{array}$ \\
\hline Nominal property prices & $\begin{array}{l}\text { GDP deflator } \\
\text { Nominal wages } \\
\text { US 3-M T-Bill rate }\end{array}$ & $\begin{array}{l}0.02 \\
0.02 \\
0.10\end{array}$ \\
\hline Unemployment rate & $\begin{array}{l}\text { Nominal wages } \\
\text { World output gap }\end{array}$ & $\begin{array}{l}0.07 \\
0.07\end{array}$ \\
\hline \multicolumn{3}{|c|}{$\begin{array}{l}\text { The unemployment rate is measured in percentage points. As exogenous variables, the estimated } \\
\text { equations include US 3-month Treasury Bill rate, the log of import prices, and a measure of the 'world' } \\
\text { output gap. All equations were estimated with two lags of the independent variables. }\end{array}$} \\
\hline $\begin{array}{l}{ }^{2} \text { The unemployment rate is measu } \\
\text { equations include the US 3-month } \\
\text { measure of the 'world' output gap. } \\
\text { variables. }\end{array}$ & $\begin{array}{l}\text { in percentage points. As ex } \\
\text { easury Bill rate, the quarterl } \\
\text { ll equations were estimated }\end{array}$ & $\begin{array}{l}\text { enous variables, the estimated } \\
\text { te of change of import prices, and a } \\
\text { h four lags of the independent }\end{array}$ \\
\hline
\end{tabular}

The importance of external factors is not surprising in view of the size and openness of the Hong Kong economy, the currency board system, and the absence of controls on capital movements. A rigidly fixed exchange rate and free movements of capital implies that credit conditions in Hong Kong will be determined predominantly in the international market as captured here by the US Treasury Bill rate. The internationally determined credit conditions will in turn influence macroeconomic conditions through their effects initially on asset prices (e.g. property prices), consumption and investment and ultimately on the general level of aggregate demand, output, and the price level. Furthermore, given the fixed exchange rate, external price developments will have an 
impact both on domestic consumer goods (and therefore on the CPI) and on imported inputs. As we will document more in detail below, the variations in the cost of imported inputs appear to be an important source of inflationary, and deflationary, pressures in Hong Kong.

Finally, external business cycle conditions as measured by the aggregate output gap in the main trading partners will be important for aggregate demand for Hong Kong output. The extreme openness of the economy means that variations in export demand is very important for the local economy. In addition it is likely that domestic economic agents will form expectations about future incomes on the basis of external developments, and this in turn will influence domestic demand.

The dependence of the domestic economy on external factors does not mean that local developments are unimportant, but it suggests that some of these developments may be determined partly by external events. For example, Peng, Cheung and Leung (2001) have shown that property price developments can have significant effects on domestic aggregate demand and hence on inflation through wealth and balance sheet effects. ${ }^{5}$ This is not inconsistent with our results which suggest that property price developments do not Granger-cause inflation or output in a multivariate context, because we would argue that property prices themselves are in part endogenous.

In the next section we propose a methodology for measuring the relative importance of foreign and domestic factors for domestic macroeconomic fluctuations in general and for the current deflation in particular.

\section{III.2 Evidence from a semi-structural VAR. ${ }^{6}$}

To estimate the relative importance of domestic and foreign shocks in the Hong Kong economy we use the framework developed in Genberg, Salemi, and Swoboda (1987) and applied to Hong Kong in Genberg (2003). We update the estimations carried out there using data until the first quarter of 2003, and we also extend the analysis by paying greater attention to the explanation of the post 1997 period.

The estimation framework is a block-triangular VAR as in equation (1)

$$
\left(\begin{array}{l}
y_{t} \\
x_{t}
\end{array}\right)=\left(\begin{array}{cc}
D_{11}(L) & D_{12}(L) \\
0 & D_{22}(L)
\end{array}\right)\left(\begin{array}{l}
y_{t-1} \\
x_{t-1}
\end{array}\right)+\left(\begin{array}{l}
\varepsilon_{t} \\
\eta_{t}
\end{array}\right)
$$

The vectors $y_{t}$ and $x_{t}$ contain respectively the domestic and foreign variables of interest. The triangular form of the matrix of coefficients on the lagged variables embodies the small open economy hypothesis according to which domestic variables have no influence on foreign variables. The system (1) can be thought of as a reduced form of a general dynamic macroeconomic model of the home economy in which the

\footnotetext{
${ }^{5}$ We are grateful to a referee for drawing our attention to this study and that of the IMF mentioned in footnote 8 below.

${ }^{6}$ This section draws heavily on Genberg (2003).
} 
small economy assumption is maintained. The reduced form errors $\varepsilon_{t}$ and $\eta_{t}$ will be functions of the structural errors, but the small economy hypothesis ensures that $\eta_{t}$ will not contain any errors from the domestic structural equations. The block-triangular structure therefore allows us a semi-structural interpretation of (1), namely that $\eta_{t}$ only contains foreign shocks. This will allow us to construct a measure of the relative importance of foreign versus domestic shocks in the economy.

The moving average representation of $y_{t}$ and $x_{t}$ is given in (2)

$$
\left(\begin{array}{l}
y_{t} \\
x_{t}
\end{array}\right)=\left[I-\left(\begin{array}{cc}
D_{11}(L) L & D_{12}(L) L \\
0 & D_{22}(L) L
\end{array}\right)\right]^{-1}\left(\begin{array}{l}
\varepsilon_{t} \\
\eta_{t}
\end{array}\right)
$$

From this we can write the forecast error at horizon $h$ of each element of $y_{t}$ as a linear combination of the VAR errors to the equation for the domestic and foreign variables

$$
y_{i, t+h}-E_{t}\left(y_{i, t+h}\right)=\sum_{d=1}^{D} \sum_{l=1}^{h} \xi_{d, l} \cdot \varepsilon_{d, t+l}+\sum_{f=1}^{F} \sum_{l=1}^{h} \psi_{f, l} \cdot \eta_{f, t+l}
$$

The variance of the forecast error is

$$
V\left[y_{i, t+h}-E_{t}\left(y_{i, t+h}\right)\right]=\sum_{d=1}^{D} \sum_{l=1}^{h} \xi_{d, l}^{2} \cdot \sigma_{\varepsilon_{d}}^{2}+\sum_{f=1}^{F} \sum_{l=1}^{h} \psi_{f, l}^{2} \sigma_{\eta_{f}}^{2}+\sum_{d=1}^{D} \sum_{f=1}^{F} \sum_{l=1}^{h} \xi_{d, l} \psi_{f, l} \sigma_{\varepsilon_{d}, \eta_{f}}
$$

In view of the small-economy assumption that says that domestic shocks do not influence foreign variables, it must be that case that the contemporaneous correlation between the VAR errors $\varepsilon_{t}$ and $\eta_{t}$ must be due to the contemporaneous effect of $x_{t}$ on $y_{t}$ and not vice versa. Hence we can decompose the variance of the forecast errors into a domestic part which is the first term of the right hand side of (4) and a foreign part corresponding to the second and third terms. A convenient way to achieve an equivalent decomposition is to estimate the variance-covariance matrix of the VAR errors and render it diagonal by a Choleski decomposition in which the foreign variables come first in the ordering. This effectively ensures that the contemporaneous correlation between $\varepsilon_{t}$ and $\eta_{t}$ is due to the contemporaneous effect of $x$ on $y$. Then we get

$$
V\left[y_{i, t+h}-E_{t}\left(y_{i, t+h}\right)\right]=D_{i, h}+F_{i, h}
$$

where

$$
\begin{aligned}
& D_{i, h}=\sum_{d=1}^{D} \sum_{l=1}^{h} \xi_{d, l}^{2} \cdot \sigma_{\varepsilon_{d}}^{2} \\
& F_{i, h}=\sum_{f=1}^{F} \sum_{l=1}^{h} \psi_{f, l}^{2} \sigma_{\eta_{f}}^{2}+\sum_{d=1}^{D} \sum_{f=1}^{F} \sum_{l=1}^{h} \xi_{d, l} \psi_{f, l} \sigma_{\varepsilon_{d}, \eta_{f}}
\end{aligned}
$$

$D_{i, h}\left(F_{i, h}\right)$ stands for the domestic (foreign) contribution to the forecast error variance of $y_{i}$ at horizon $h$. The relative contribution of foreign variables to the forecast error of each domestic variable is therefore simply 


$$
R E L_{i, h}^{F}=\frac{F_{i, h}}{D_{i, h}+F_{i, h}}
$$

To compute this we first estimate the VAR as shown in (1), i.e. imposing the block-triangular structure between domestic and foreign variables. We then orthogonalize the errors using the Choleski factorization of the variance-covariance matrix. Finally we calculate the forecast error variance decomposition and compute $\mathrm{REL}^{\mathrm{F}}$ for each of the domestic variables. We use the same variables as in the Granger-causality tests, namely the GDP deflator, nominal wage rates, nominal property prices, and the unemployment rate as domestic variables and the US 3-month Treasury Bill rate, unit value of Hong Kong imports, and a measure of the output gap in Hong Kong's main trading partners as the foreign variables. ${ }^{7}$

The estimates of the relative importance of foreign shocks in the Hong Kong economy given in Table III.2 are consistent with those presented in Genberg (2003). Forecast errors of the GDP deflator are predominantly due to foreign factors at horizons longer than 4 quarters. The same can be said for property prices. Nominal wages are influenced by a larger proportion of domestic shocks at short- to medium horizons, and the measure of the relative importance of foreign shocks only reaches $50 \%$ at the 3 -year horizon. The unemployment rate lies in between the two price indices and the wage rate in terms of its dependence on foreign variables. At the horizon of one year two-thirds of the forecast error variance is accounted for by domestic shocks but this proportion falls to less that one third at the 3 year horizon.

\footnotetext{
${ }^{7}$ All variables except the unemployment rate, the US interest rate, and the world output gap were expressed in log-levels. Five lags of each variable were included in each equation. Genberg (2003) contains robustness checks of the main results using different combinations of domestic and foreign variables, and different lag lengths in the VAR.
} 


\section{Table III.2. Contribution of foreign variables to the forecast error variance of domestic variables. ${ }^{1}$}

(Percent)

\begin{tabular}{|c|c|c|c|c|}
\hline Horizon & $\mathrm{P}^{\mathrm{GDP}}$ & $\mathrm{W}$ & $\mathrm{U}$ & $\mathrm{P}^{\text {PROP }}$ \\
\hline 1 & 24 & 6 & 2 & 4 \\
\hline 4 & 64 & 5 & 33 & 56 \\
\hline 8 & 73 & 22 & 60 & 77 \\
\hline 12 & 77 & 50 & 72 & 79 \\
\hline 16 & 82 & 68 & 75 & 82 \\
\hline
\end{tabular}

${ }^{1}$ Sample period: 1984:1-2003:1. The domestic variables are the log of the GDP deflator ( $\mathrm{P}^{\mathrm{GDP}}$ ), the $\log$ of nominal wages $(\mathrm{W})$, the unemployment rate in percent $(\mathrm{U})$, and the log of the property price index $\left(\mathrm{P}^{\mathrm{PROP}}\right)$. The foreign variables are the US three-month Treasury bill rate, the log of the unit value of imports of Hong Kong, and a measure of the foreign output gap.

What do the estimates imply for the sources of the deflation since 1997? One way to answer this question is to make use of the fact that in VARs it is possible to decompose the in-sample actual value of each variable into one part that is forecast on the basis the estimated dynamics of the system and another part that depends on shocks that have occurred during a particular time period. To be specific, equation (3) above can be rewritten as

$$
y_{i, t}-y_{i, t-h}=E_{t-h}\left(y_{i, t}-y_{i, t-h}\right)+\sum_{d=1}^{D} \sum_{l=1}^{h} \xi_{d, l} \cdot \varepsilon_{d, t-h+l}+\sum_{f=1}^{F} \sum_{l=1}^{h} \psi_{f, l} \cdot \eta_{f, t-h+l}
$$

The interpretation of this relationship is as follows. The actual change in the variable $y_{i}$ from time $t$ - $h$ to time $t$ can be decomposed into (i) a forecast or expected change (as of period $t-h$ ) which is the first term on the right hand side, (ii) the consequence of shocks to domestic variables in the time interval $t$ - $h$ to $t$ (the second term), and (iii) the consequence of shocks to foreign variables in the same time interval (the third term). The forecast, $E_{t-h}\left(y_{i, t}-y_{i, t-h}\right)$, represents the delayed effects implicit in the dynamics of the entire VAR system.

In this section this decomposition is used to illustrate the relative importance of predictable factors, foreign shocks, and domestic shocks for the evolution of output growth and inflation during the deflation since 1997. We use the estimated values of the domestic and foreign shocks to decompose the path for these two variables from the last quarter of 1996 ( $t-h$ in the equation) until the end of the sample. In each case the paths of two counterfactual variables are calculated and presented in charts together with the actual values:

- 'No Shocks' which is simply $E_{t-h}\left(y_{i, t}\right)$ 
- 'Foreign shocks only' which is defined by $E_{t-h}\left(y_{i, t}\right)+\sum_{f=1}^{F} \sum_{l=1}^{h} \psi_{f, l} \cdot \eta_{f, t-h+l}$

We start describing the results for the GDP deflator and the nominal wage index together with the corresponding inflation rates. Figures III.1 and III.2 show that both the price level and the wage level in 2003 are around the level they would have been if only external shocks had influenced the Hong Kong economy since 1997. This is in line with the view that over long enough horizons, developments in the economy are dominated by shocks originating abroad. This long-term view hides the fact that domestic deflationary shocks have been relatively important in the intervening period. From its peak in the fourth quarter of 1997, the GDP deflator fell during the subsequent three years by some $14.7 \%$. Had there been no shocks the model would have predicted a decline by $1.9 \%$, and taking account the external shocks during 1997-2000, the model can explain a decline of $9.4 \%$. In other words, domestic factors accounted for slightly over five percentage points of the total decline. ${ }^{8}$ For wages a similar pattern is visible. With only foreign shocks, the model would have predicted an increase of wages of 5.4\% whereas the actual increase was only $1.3 \%$. Domestic shocks thus exerted downward pressures on wages of $4.1 \%$ over this period.

During the 2001-03 period the patterns are reversed, which is best seen in Figures III.1a and III.2a that contain the year-on-year inflation rates calculated from the data underlying Figures III.1 and III.2. The growth rates of both the price and wage series are now higher than predicted by the effects of foreign shocks alone. In other words, domestic factors were exerting inflationary pressures during this period.

Turning to the behavior of the unemployment rate (Figure III.3) we also note a difference between the period from the beginning of 1998 to the end of 2000 and the period thereafter. In the first period, domestic shocks keep the unemployment rate higher than they would have been in their absence, whereas in the second period the reverse is true. Note, however, that foreign factors are considerably more important than the domestic ones. For example from the first quarter of 1997 until the fourth quarter of 1999 , the actual unemployment rate increased from $2.3 \%$ to $6.3 \%$, of which only one percentage points can be explained by domestic factors. Similarly, the cumulative effects of inertia and foreign shocks would have predicted an unemployment rate of just over $8 \%$ in the beginning of 2003 when the actual rate was $7.5 \%$. Domestic expansionary factors have had an effect of about half a percentage point.

\footnotetext{
${ }^{8}$ It is possible that price developments in the property sector are responsible for this as suggested by Peng, Cheung and Leung (2001) and IMF (2002).
} 

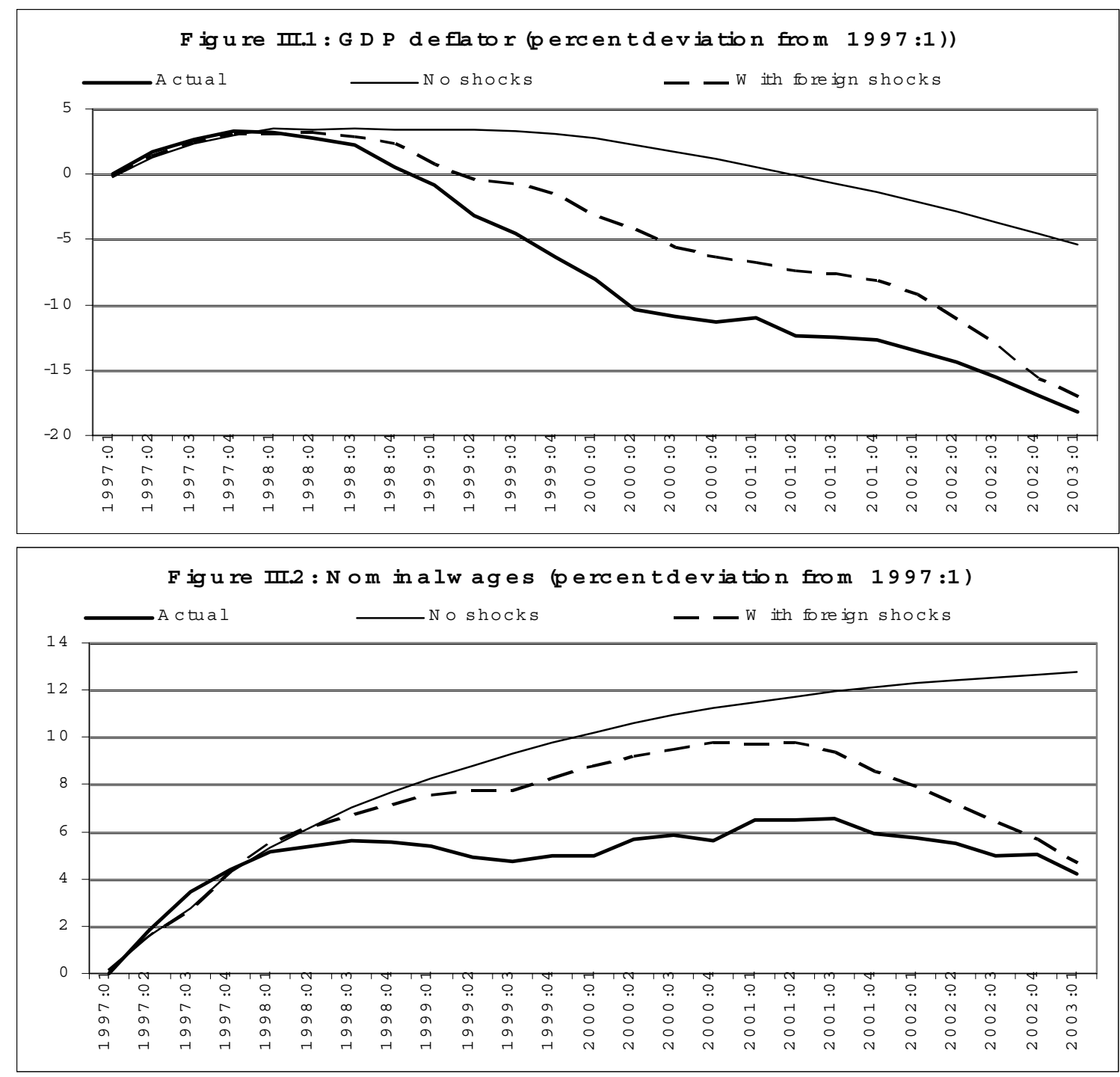

F ig u re III.1 a : Inflation ( $y-0-y \%$ changes in G D P deflator)

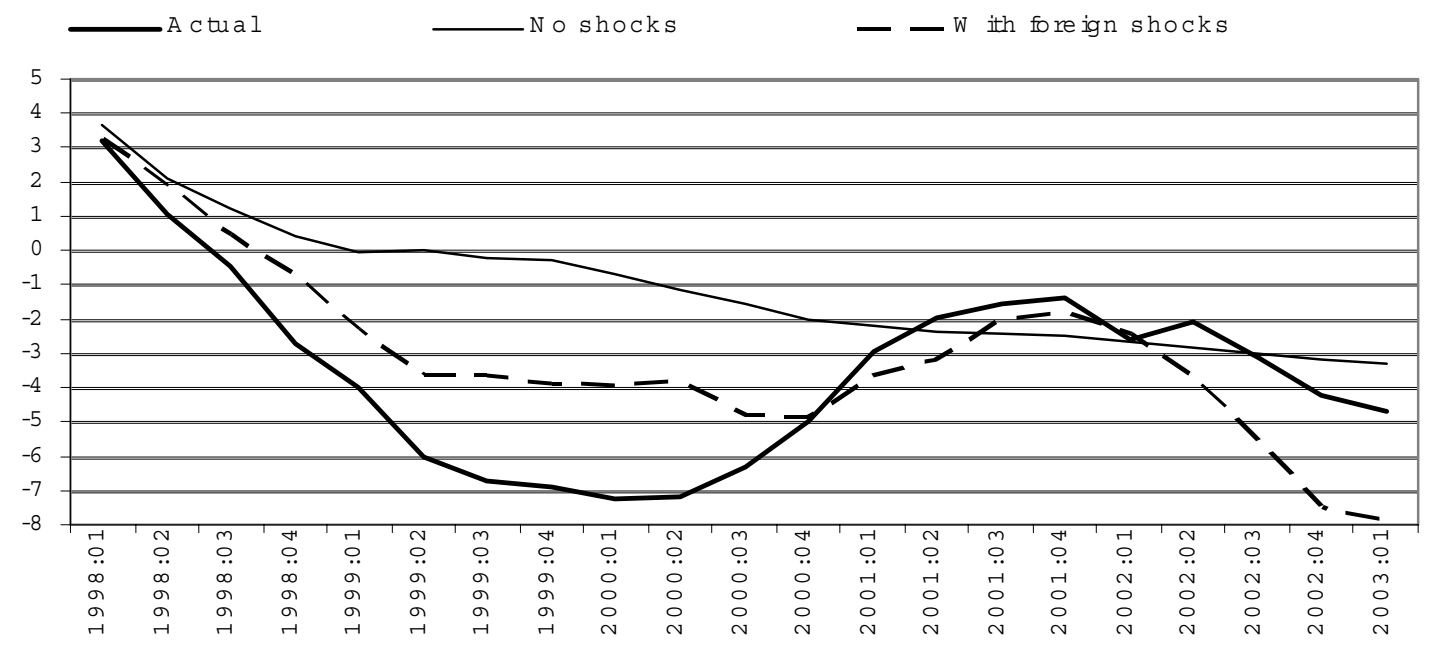



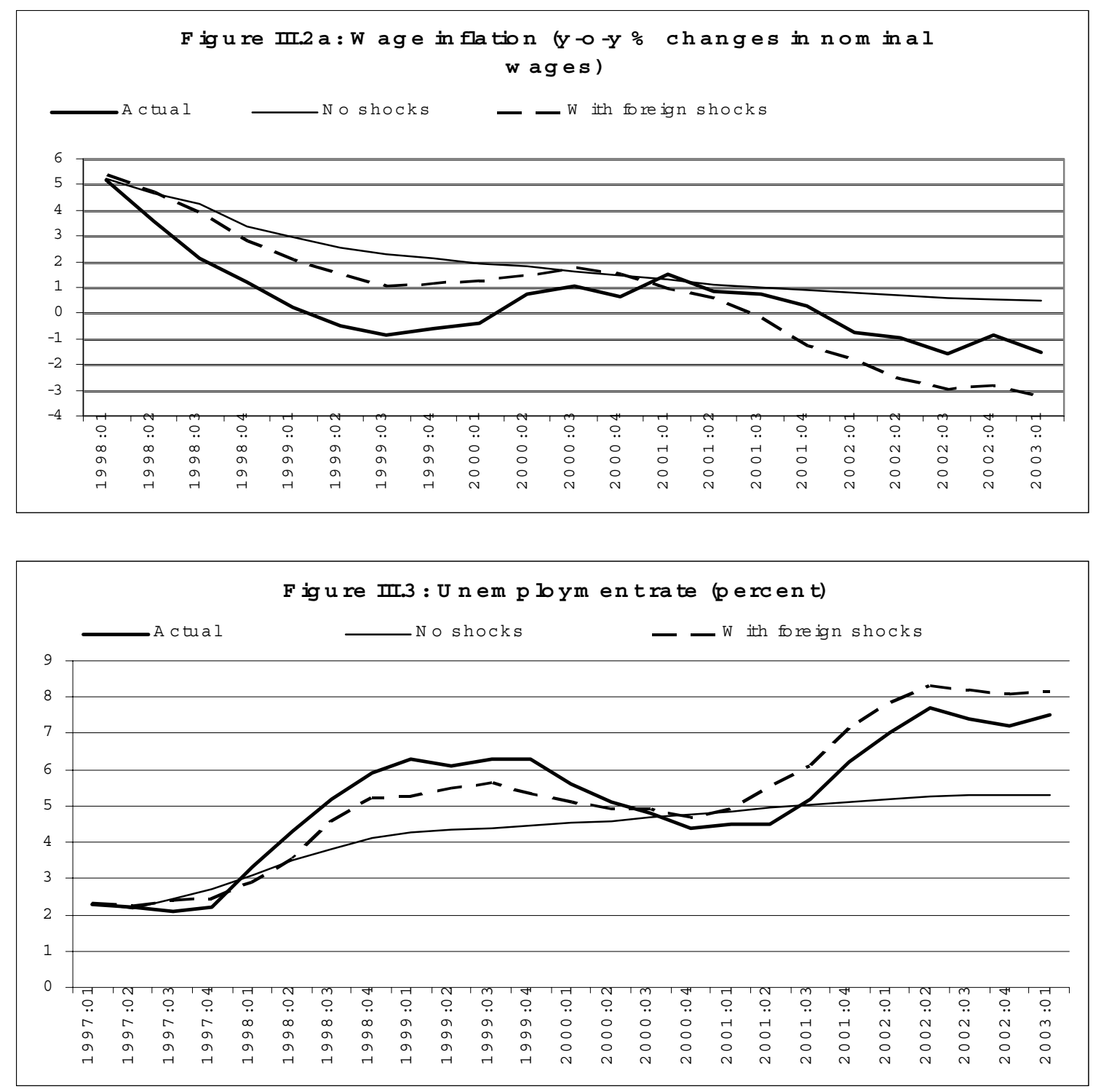

Taken together the behavior of prices, wages, and unemployment since 1997 suggest an international environment which was decidedly deflationary from 1998 until the second half of 1999 and again from 2001 until the second half of 2003. Domestic factors contributed to the deflation from 1998 until the end of 2000 after which they have been somewhat inflationary.

It would be tempting to use the estimated VAR to separate the effects of the domestic shocks into their individual components. Unfortunately, in the absence of some identifying restrictions that would allow us recuperate the structural shocks from the reduced form VAR disturbances (the $\varepsilon_{t}$ in equation (1)), we are not able to do so. Instead in the next section we shall search for structural explanations of the results obtained here 
by estimating equations explaining the wage and price inflation as well as the unemployment rate.

\section{Structural interpretations of the wage-price-unemployment nexus.}

IV.1 The inflation process.

Much of the recent literature on inflation dynamics has focused on theoretical developments and empirical applications of the New Keynesian Phillips curve (NKPC). Influential contributors to this literature have been Galí and Gertler (1999) [henceforth GG] who estimated their New Hybrid Keynesian Phillips curve for the USA, and Galí, Gertler and López-Salido (2001) [henceforth GGLS] who applied the framework to the Euro area. The theoretical model is based on the Calvo (1983) sticky price and Taylor (1980) sticky wage framework and implies that firms set prices as mark-ups over the marginal cost of production. The empirical applications typically focus on the behavior of wages and labor productivity as components of marginal cost. ${ }^{9}$

The main findings of GG (1999) and GGLS (2001) can be summarized in four points: (1) firms are found to be forward-looking, (2) the degree of price stickiness is substantial, on average about 5 quarters in the Euro area and 4 quarters in the US, ${ }^{10}$ (3) the backward-looking behaviour is statistically but not quantitatively important, (4) the New Keynesian Phillips curve provides a good description of inflation dynamics

The model used in GG (1999) and GGLS (2001), however, only features labor as the variable input in the cost function. Genberg and Pauwels (2003a, 2004) apply the NKPC paradigm to Hong Kong but argue that imported intermediate goods are an important factor of production in the context of open economies. Firms that set prices in relation to marginal cost therefore take into account not only labor cost but also the cost of imported intermediate inputs. Our open economy model nests Galí and Gertler's (1999) hybrid model as a special case when imported inputs are negligible. In this section we summarize the basic structure of our open economy version of the NKPC and report results we have obtained when we confront it with date from Hong Kong.

\section{The New Hybrid Keynesian Phillips curve}

The new hybrid Keynesian Phillips curve is based on Calvo (1983) sticky price model emphasising forward-looking behaviour of firms. Each period, a fraction 1- $\theta$ of firms in the economy adjust their prices, while the remainder are constrained to keeping them fixed. The parameter $\theta$ is thus a measure of the degree of price stickiness. Since

\footnotetext{
${ }^{9}$ The empirical application of the GG (1999) approach is not without controversy. Both the use of unit labour cost and rational expectations in their model have been criticised by Roberts (2001), Rudd and Whelan (2001) and Lindé (2001), who's results do not concur with those of Galí and Gertler (1999). Galí, Gertler and López-Salido (2003) formulate a response showing that their model is robust to the criticism. Moreover, econometric problems associated with instrumental variable estimation tend to affect the results obtained for the NKPC (see Stock, Wright and Yogo (2002) for a weak instruments and identification survey).

${ }^{10}$ It should be noted that the degree of price stickiness is not precisely estimated in these studies. For example, GGLS present estimates from 2 quarters to 17 quarters for the Euro Area.
} 
firms are assumed identical, the proportion of firms adjusting at time $t$, will choose the same optimal price $p_{t}^{*}$. The aggregate price level therefore follows

$$
p_{t}=\theta p_{t-1}+(1-\theta) p_{t}^{*}
$$

Gali and Gertler (1999) assume that a fraction $(1-\kappa)$ of the firms set prices optimally in a forward-looking fashion and while a fraction $\kappa$ set prices using an average of optimally adjusted prices from the previous period plus a correction for past inflation $\left(\pi_{t-1}\right)$. Hence

$$
p_{t}^{*}=(1-\kappa) p_{t}^{f}+\kappa p_{t}^{b}
$$

where

$$
\begin{aligned}
& p_{t}^{f}=\mu+(1-\beta \theta) \sum_{k=0}^{\infty}(\beta \theta)^{i} E_{t}\left[m c_{t+k}^{n}\right] \\
& p_{t}^{b}=p_{t-1}^{*}+\pi_{t-1}
\end{aligned}
$$

where $p_{t}^{f}$ is the price set by the forward looking agent and $p_{t}^{b}$ is that set by their backward-looking counterparts.

The implied reduced form of the hybrid NKPC can be written as

$$
\pi_{t}=\delta^{h} \cdot \hat{m c_{t}}+\omega^{f} E_{t}\left\{\pi_{t+1}\right\}+\omega^{b} \pi_{t-1}+\varepsilon_{t}
$$

where $\beta$ is the subjective discount factor and $m c_{t}$ the deviation of the log of real marginal cost from its steady-state value. The relationship between the structural parameters and the reduced from coefficients is defined by

$$
\begin{aligned}
& \delta \equiv(1-\kappa)(1-\theta)(1-\beta \theta) \psi^{-1} \\
& \omega^{f} \equiv \beta \theta \psi^{-1} \\
& \omega^{b} \equiv \kappa \psi^{-1} \\
& \text { and } \\
& \psi \equiv \theta+\kappa[1-\theta(1-\beta)]
\end{aligned}
$$

As done in the literature we assume that $\beta=1$ implying that $\omega^{f}+\omega^{b}=1$.

\section{Micro-Foundations}

The marginal cost measure presented in GG (1999) is derived from basic principles of microeconomics. Generally, the cost minimizing problem for $n$ inputs can be written as: $\operatorname{Min}_{X_{i, t}} C_{t}=\sum_{i=1}^{n} w_{i, t} X_{i, t}$, with $w_{i, t}$ as the $i^{\text {th }}$ input price valued at time $t$ and $X_{i, t}$ is the $i^{t h}$ input at time $t$, subject to the production function $Y_{t}=f\left(X_{i, t} ; \alpha_{i}\right)$. We assume a 
Cobb-Douglas production function so that $Y_{t}=A \prod_{i=1}^{n} X_{i, t}^{\alpha_{i}}$ with $\sum_{i=1}^{n} \alpha_{i}=1$. The first order conditions yield the following shadow price in real terms:

$$
\lambda_{t}^{\text {real }}=\frac{w_{i, t} X_{i, t}}{\alpha_{i} P_{t} Y_{t}}, \quad \forall i
$$

where $P_{t}$ is the output price. After taking the natural logarithm and deviations from steady state values, we can define a multi-input-marginal-cost gap measure by:

$$
\hat{\operatorname{mimc}_{t}}=\sum_{i=1}^{n} \xi_{i}\left(s_{i, t}-s_{i, t}^{*}\right)
$$

so,

$$
\hat{\operatorname{mimc}_{t}}=\sum_{i=1}^{n} \xi_{i}\left(\hat{s}_{i, t}\right)
$$

where $s_{i, t}=\ln \left(\frac{w_{i, t} X_{i, t}}{P_{t} Y_{t}}\right)$ and where $s_{i, t}^{*}$ is the steady-state value of the ith input income share and $\sum_{i=1}^{n} \xi_{i}=1$.

\section{Open-Economy Marginal Costs}

Galí and Gertler's model has captured inflation dynamics in the USA and EU fairly well using solely the wage rate that in turn influences marginal cost. This may not be the case in the context of open economies, where it is believed that external inflation may have a more direct influence on domestic inflation. Genberg and Pauwels (2003b) argue that price setting in a highly open economy is likely to be influenced by foreign prices through intermediate inputs, as formulated in Galí and López-Salido (2000) for their analysis of Spanish inflation. Gagnon and Khan (2001) have attempted to modify the marginal cost measure through the use of different types of production functions. Open economy considerations also have been introduced in structural models of price setting by Galí and Monacelli (2000) and Balakrishnan and López-Salido (2002).

In the two inputs case using labour $\left(L_{t}\right)$ and intermediate imports $\left(M_{t}\right)$, the specification yields the following first order condition:

$$
\lambda_{t}=\frac{w_{t} L_{t}}{\alpha Y_{t}}=\frac{P_{t}^{i m} M_{t}}{(1-\alpha) Y_{t}}
$$

As before we can define the following weighted average cost measure by:

$$
\stackrel{\wedge m c_{t}}{=}=\xi \hat{s}_{t}^{L}+(1-\xi) \hat{s}_{t}^{i m}
$$


where $o m c_{t}$ is the open economy measure of the deviation of marginal cost from its steady state value. The parameter $\xi$ is between 0 and $l$ and needs to be determined. When $\xi$ is equal to 1 , the model collapses to the specification by GG (1999) featuring only labors costs.

The final expression for the rate of inflation is:

$$
\pi_{t}=\delta^{h} \cdot \hat{o m c}_{t}+\omega^{f} E_{t}\left\{\pi_{t+1}\right\}+\omega^{b} \pi_{t-1}+\varepsilon_{t}
$$

with the relationship between the coefficients and the structural parameters as defined above following equation (7).

\section{Application to Hong Kong}

We estimated the model for a sample extending from the first quarter 1984 until the fourth quarter of 2002, as well as for a sub-sample spanning 1984 Q1 - 1997 Q2 to check whether excluding the deflationary period of the sample has an impact on the estimates. Inflation $\left(\pi_{t}\right)$ was measured as the log difference of the GDP deflator, and the marginal cost variable was constructed using a seasonally adjusted nominal wage index and a seasonally adjusted quarterly unit value index of imports. To deal with the endogeneity of $E_{t}\left\{\pi_{t+1}\right\}$ and $o m c_{t}$, we used lagged values of the inflation rate, current and lagged values of CPI inflation in Hong Kong's main trading partners, and current lagged values of import price inflation as instruments. A detailed discussion of the estimation strategy can be found in GP (2004). Here we simply highlight the main conclusions.

Table IV.1 shows estimated reduced form coefficients as well as the implied structural parameters from specifications which yielded the most significant coefficient $\left(\delta^{h}\right)$ on the marginal cost measure, as judged by the p-value.

For the full sample, the estimated weight $(\xi)$ on labour cost is typically less than one half. In the preferred specification shown in the table, only values between 0 and 0.3 give positive and statistically significant values of $\delta^{h}$. This implies that when firms adjust prices as mark-up over marginal cost, they place more weight on imported input costs than on wage costs. In Hong Kong the evidence clearly indicates that open economy considerations must be taken into account in modelling inflation along the line of the NKPC.

The estimate of the parameter $\kappa$ implies that about half of the firms set prices in a completely forward-looking manner, while the estimate of $\theta$ suggests that between 46 and 49 percent of firms adjust prices each quarter. As a consequence, the mean lag of price adjustments is estimated to be between 2.4 and 3.3 quarters. This is somewhat 
shorter than the estimates found for the USA and the Euro Area indicating that price flexibility in Hong Kong is relatively high.

Turning to the results for the shorter sample which excludes the deflation since 1mid-1997, we note three main differences. First, the importance of labor in the marginal cost measure is greater in the earlier period. This is consistent with an evolution of the Hong Kong economy away from labour-intensive production. Second, the estimate of the effect of marginal cost on current inflation is larger in the earlier sample. This might be the result of greater pricing power of firms when production has shifted towards more high-value-added products, but it does seem to be inconsistent with the process of price convergence with the mainland. Finally, the estimate of $\kappa$, the proportion of price setters which are backward-looking, is smaller for the pre-crisis period.

Table IV.1: Estimation of the Open Economy New Keynesian Phillips Curve.

Sample 1984:1 to 2002:4

\begin{tabular}{|c|c|c|c|c|c|}
\hline & \multicolumn{2}{|c|}{$\begin{array}{l}\text { Reduced form } \\
\text { coefficients }\end{array}$} & \multicolumn{2}{|c|}{$\begin{array}{l}\text { Implied structural } \\
\text { parameters }\end{array}$} & \multirow{2}{*}{$\begin{array}{c}\begin{array}{c}\text { Price stickiness } \\
\text { (in quarters) } \\
1 /(1-\theta)\end{array} \\
3.3\end{array}$} \\
\hline \multirow{2}{*}{$\xi=0$} & $\delta^{h}$ & $\begin{array}{l}0.038 \\
(0.01)\end{array}$ & $\theta$ & 0.7 & \\
\hline & $\omega^{\mathrm{f}}$ & $\begin{array}{l}0.58 \\
(0.138)\end{array}$ & $\kappa$ & 0.5 & \\
\hline \multirow{2}{*}{$\xi=0.3$} & $\delta^{h}$ & $\begin{array}{l}0.074 \\
(0.031)\end{array}$ & $\theta$ & 0.58 & 2.4 \\
\hline & $\omega^{\mathrm{f}}$ & $\begin{array}{l}0.52 \\
(0.141)\end{array}$ & $\kappa$ & 0.54 & \\
\hline $\begin{array}{l}\text { Notes: T } \\
\text { current }\end{array}$ & $\begin{array}{l}\text { nt set } \\
\text { CPI }\end{array}$ & $\begin{array}{l}\text { nsists } \\
\text { lation }\end{array}$ & $\begin{array}{l}\text { of dom } \\
\text { ading } p\end{array}$ & $\begin{array}{l}\text { inflatic } \\
\text { ers and }\end{array}$ & $\begin{array}{l}\text { o lags and the } \\
\text { ice inflation. }\end{array}$ \\
\hline
\end{tabular}

Sample 1984:1 to 1997:2

\begin{tabular}{|l|r|l|r|l|c|}
\hline \multirow{3}{*}{$\xi=0.5$} & \multicolumn{2}{|c|}{$\begin{array}{c}\text { Reduced form } \\
\text { coefficients }\end{array}$} & \multicolumn{2}{|c|}{$\begin{array}{c}\text { Implied structural } \\
\text { parameters }\end{array}$} & $\begin{array}{c}\text { Price stickiness } \\
\text { (in quarters) } \\
1 /(1-\theta)\end{array}$ \\
\cline { 2 - 6 } & $\delta^{\mathrm{h}}$ & $\begin{array}{l}0.118 \\
(0.034)\end{array}$ & $\theta$ & 0.68 & 3.1 \\
\hline & $\omega^{\mathrm{f}}$ & $\begin{array}{l}0.89 \\
(0.127)\end{array}$ & $\kappa$ & 0.08 & \\
\hline \multirow{3}{*}{$\xi=0.55$} & $\delta^{\mathrm{h}}$ & $\begin{array}{l}0.102 \\
(0.028)\end{array}$ & $\theta$ & 0.72 & 3.6 \\
\cline { 2 - 6 } & $\omega^{\mathrm{f}}$ & $\begin{array}{l}0.97 \\
(0.098)\end{array}$ & $\kappa$ & 0.02 & \\
\hline \multicolumn{7}{|l|}{} \\
\hline \multicolumn{7}{|l|}{$\begin{array}{l}\text { Notes: The instrument set consists of 5 lags of domestic inflation and two lags and the } \\
\text { current values of the CPI inflation of main trading partners and import price inflation. }\end{array}$} \\
\hline
\end{tabular}


In spite of these changes in the results, the degree of price stickiness does not appear to have changed over time. Hong Kong has been and remains an economy with relatively high degree of price flexibility.

\section{IV.2 Wage dynamics.}

In the model of inflation that we estimated in the previous section, the domestic wage rate is an important driving force, even if we have argued that it does play second fiddle to external price impulses. To gain further insights into the inflation process we therefore specify and estimate an equation describing domestic wage movements. It is based on a framework suggested by Blanchard and Katz (1999) in which rate of change in nominal wages is a function of expected inflation, productivity growth, a measure of demand, and a type of error-correction term according to which real wages in excess of those warranted by productivity leads to downward nominal wage adjustments, i.e.

$$
w_{t}-w_{t-1}=\alpha_{0}+\alpha_{1}\left(p_{t}^{e}-p_{t-1}\right)+\alpha_{2} \text { prod_growth }_{t}+\alpha_{3} d_{t}+\alpha_{4}\left[\ln \left(\frac{W}{P}\right)_{t-1}-\omega_{t-1}\right]
$$

where $w_{t}$ stands for the nominal wage rate, $p_{t}$ for the price level, $d_{t}$ for a measure of excess demand, and $\omega_{t}$ for the equilibrium real wage rate. Lower case letters refer to the natural logarithm of the corresponding capital letters. We expect $\alpha_{1}, \alpha_{2}$, and $\alpha_{3}$ to be positive and $\alpha_{4}$ to be negative.

\section{Data.}

For the price level we used the consumer price index. In the empirical application we replaced the expected rate of price inflation with the current rate and used instrumental variables to project this rate on lagged information. ${ }^{11}$ Labor productivity was measured as real GDP per hour worked. The productivity growth variable used in the regression is the quarterly growth rate in this measure smoothed using the HodrickPrescott filter with a smoothing parameter of 1600 . The excess real wage term, $\left[\ln \left(\frac{W}{P}\right)_{t-1}-\omega_{t}\right]$, real wage gap for short, was obtained as the residual from a regression of the $\log$ of the real wage rate on a constant and the log of labor productivity.

\section{Results.}

Table IV. 2 contain coefficient estimates obtained when a measure of the output gap is used as the demand variable. ${ }^{12}$ The first column shows the results corresponding to the whole sample from 1984 until 2003. All coefficients have the correct signs and all except the one on the error-correction term are highly significant. The size of the

\footnotetext{
${ }^{11}$ See Table IV.1 for an explanation of the estimation technique and the instruments used.

12 The output gap was measured as the difference between the log of real gdp and the HP filtered (smoothing parameter $=1600$ ) of the same series.
} 
coefficient on the output gap implies that a gap of 5 percentage points (the mean absolute value of the series is 2.2 percent and the maximum is 8.2 percent) will increase wage inflation by $0.5 \%$ in the current quarter. The coefficient on the real wage gap implies that if real wages are 5 percentage points above their equilibrium level (as measured here) the nominal wage rate will adjust downward by $.47 \%$ in the current quarter. ${ }^{13}$ These estimates imply a certain sluggishness in the adjustment of the wage rate to changes in prices and demand conditions. For example, an increase of 5 percent in the CPI would lead to an immediate increase in wages of about 3 percent and hence a wage gap of minus two percent. The wage gap would by itself increase wages about 0.8 percent during the following four quarters. However, there would likely be other factors influencing the wage process as well. As we shall see in the next section, the reduction in wages will have competitiveness effects increasing the output gap, which in turn will increase wages. In addition, the inflation model estimated in the previous section implies that there will be feedback from the wage rate onto the price level. ${ }^{14}$

Foreign variables do not enter the wage equation directly, but they do have indirect effects. An increase in import prices influences both the GDP deflator (see the previous section) and the consumer price index (see footnote 4). Hence they will influence wages both concurrently and with a lag as described above. Changes in external demand will also influence wages indirectly since, as we shall see in the next section, foreign output fluctuations have a direct influence on the domestic output gap.

\footnotetext{
${ }^{13}$ The mean of the absolute values of the real wage gap is $2.6 \%$ and the maximum is $10.1 \%$.

${ }^{14}$ Note that we assume that it is the consumer price index that is important for the wage process, whereas the inflation model estimated in the previous section used the GDP deflator a the dependent variable. The two are clearly related. A simple OLS regression of the quarterly CPI inflation rate on the corresponding rate of change of the GDP deflator and the inflation rate of imported goods gives $\pi^{\mathrm{cpi}}=.02+.60 \pi^{\mathrm{gdp}}+$ $.24 \pi^{\mathrm{imp}}$.
} 


\begin{tabular}{|c|c|c|c|c|c|c|c|}
\hline \multicolumn{8}{|c|}{ Table IV.2: Determinants of wage inflation ${ }^{1}$} \\
\hline & (1) & (2) & (3) & (4) & (5) & (6) & (7) \\
\hline$\Delta \log \left(\mathrm{CPI}_{\mathrm{t}}\right)$ & $\begin{array}{c}.61 \\
(.06) \\
\end{array}$ & $\begin{array}{r}.59 \\
(.05) \\
\end{array}$ & $\begin{array}{r}.52 \\
(.04) \\
\end{array}$ & $\begin{array}{r}.52 \\
(.04) \\
\end{array}$ & $\begin{array}{c}.58 \\
(.05) \\
\end{array}$ & $\begin{array}{c}.66 \\
(.05) \\
\end{array}$ & $\begin{array}{r}.53 \\
(.04) \\
\end{array}$ \\
\hline$y$-gap & $\begin{array}{c}.10 \\
(.05)\end{array}$ & $\begin{array}{l}.19 \\
(.05)\end{array}$ & $\begin{array}{c}.32 \\
(.04)\end{array}$ & $\begin{array}{l}.28 \\
(.04) \\
\end{array}$ & $\begin{array}{c}.19 \\
(.06)\end{array}$ & $\begin{array}{c}.01 \\
(.05)\end{array}$ & $\begin{array}{c}.28 \\
(.06) \\
\end{array}$ \\
\hline Prod_growth(HP) & $\begin{array}{c}.60 \\
(.09) \\
\end{array}$ & $\begin{array}{c}.79 \\
(.06) \\
\end{array}$ & $\begin{array}{c}.93 \\
(.05) \\
\end{array}$ & $\begin{array}{c}.87 \\
(.05) \\
\end{array}$ & $\begin{array}{c}.66 \\
(.07) \\
\end{array}$ & $\begin{array}{c}.73 \\
(.06) \\
\end{array}$ & $\begin{array}{c}.87 \\
(.07) \\
\end{array}$ \\
\hline Wage-gap ${ }_{t-1}$ & $\begin{array}{c}-.094 \\
(.069)\end{array}$ & $\begin{array}{c}-.26 \\
(.03) \\
\end{array}$ & $\begin{array}{c}-.30 \\
(.06) \\
\end{array}$ & $\begin{array}{c}-.35 \\
(.05) \\
\end{array}$ & $\begin{array}{c}-.083 \\
(.040)\end{array}$ & $\begin{array}{c}-.28 \\
(.02) \\
\end{array}$ & $\begin{array}{c}-.28 \\
(.05) \\
\end{array}$ \\
\hline$\Delta \log \left(\mathrm{CPI}_{\mathrm{t}}\right) *$ Deflation & & $\begin{array}{c}-.65 \\
(.13) \\
\end{array}$ & & $\begin{array}{c}-.48 \\
(.07) \\
\end{array}$ & & $\begin{array}{c}-.82 \\
(.12) \\
\end{array}$ & \\
\hline Wage-gap $_{\mathrm{t}-1} *$ Deflation & & & $\begin{array}{c}.23 \\
(.07) \\
\end{array}$ & $\begin{array}{c}.08 \\
(.05) \\
\end{array}$ & & & $\begin{array}{c}.20 \\
(.07) \\
\end{array}$ \\
\hline$y$-gap ${ }_{t} *$ Deflation & & & & & $\begin{array}{c}.28 \\
(.12)\end{array}$ & $\begin{array}{c}.41 \\
(.07)\end{array}$ & $\begin{array}{c}.07 \\
(.08)\end{array}$ \\
\hline Constant & $\begin{array}{c}.013 \\
(.002) \\
\end{array}$ & $\begin{array}{c}.006 \\
(.002) \\
\end{array}$ & $\begin{array}{c}.005 \\
(.002) \\
\end{array}$ & $\begin{array}{c}.008 \\
(.001) \\
\end{array}$ & $\begin{array}{c}.013 \\
(.002) \\
\end{array}$ & $\begin{array}{c}.007 \\
(.003)\end{array}$ & $\begin{array}{c}.007 \\
(.007)\end{array}$ \\
\hline $\begin{array}{l}1 \text { Dependent variable: } \Delta \log (\mathrm{V} \\
\text { dependent and the independe } \\
\text { 2003:2. Standard errors are }\end{array}$ & $\begin{array}{l}\text { All equat } \\
\text { variables } \mathrm{i} \\
\mathrm{n} \text { in paren }\end{array}$ & $\begin{array}{l}\text { s are est } \\
\text { ach equa } \\
\text { ses. }\end{array}$ & $\begin{array}{l}\text { mated wit } \\
\text { ion. The }\end{array}$ & $\begin{array}{l}\text { GMM. In } \\
\text { mple per }\end{array}$ & $\begin{array}{l}\text { strument } \\
\text { od for all }\end{array}$ & $\begin{array}{l}\text { are four la } \\
\text { quations }\end{array}$ & $\begin{array}{l}\text { ys of the } \\
984: 1 \text { to }\end{array}$ \\
\hline
\end{tabular}

The remaining columns in Table IV.2 contain estimates of equations intended to test whether the wage adjustment process is different during the deflation period since 1997 compared to before. The estimation strategy is to create a dummy variable, 'deflation', which equals zero from 1984:1 to 1997:4 and one thereafter and to interact this variable with the CPI inflation rate, the output gap, and the real wage gap. ${ }^{15,16}$

When the reaction to the CPI inflation rate is allowed to be different in the deflation period (column (2)) the coefficient falls to zero. ${ }^{17}$ This implies a slower reaction of wages to consumer prices. It should be noted, however, that the reaction to both the real wage gap and the output gap is increased which partially, but not fully, compensates for the slower reaction to prices. The remaining columns essentially tell a similar story of attenuated reactions of wages to price shocks in the deflation period. Column (3) shows

\footnotetext{
${ }^{15}$ The productivity growth rate is almost constant in the deflation period so it was not possible to interact this variable with the deflation dummy.

${ }^{16}$ An alternative strategy would be to test whether the adjustment process is different when the price level increases as compared to when it decreases. For our sample this is almost identical to our strategy because a dummy variable that would distinguish between increasing and decreasing CPI is the same as our deflation dummy except for three observations (out of a total of seventy six). The results with the alternative specification (available from the author on request) are therefore very similar to the ones we report in Tables IV.2 and IV.3.

${ }^{17}$ The point estimate is actually negative, but not significantly different from zero.
} 
that the reaction to the real wage gap falls, and column (4) implies that the reaction to both prices and the real wage gap is lower. Column (6) shows that when the reaction to both price inflation and the output gap are allowed to change, the former decreases, where the latter increases. The combined effect again implies a slower reaction of wages to price shocks. ${ }^{18}$

Table IV. 3 contain results for regressions that are similar to those in Table IV.2 except that the unemployment rate replaces the output gap as the demand measure in equation (9). The sign of the estimates in col. (1) again correspond to what the underlying model predicts. In contrast with the previous table, however, the coefficient on the CPI inflation rate is not significantly different from zero implying that transmission of price shocks would occur only through the lagged effects on the real wage gap and the unemployment rate. When the interaction terms are included in the regressions, the results in columns (4) and (6) show similar effects as in the previous table. The response to prices is significant in the pre-deflation period, but fall to zero during the deflation. The response to the real wage gap also falls during the deflation period (col. 4), whereas the response to the unemployment rate is essentially unchanged (col. 6).

\begin{tabular}{|c|c|c|c|c|c|c|c|}
\hline \multicolumn{8}{|c|}{ Table IV.3: Determinants of wage inflation ${ }^{1}$} \\
\hline & $(1)$ & $(2)$ & (3) & (4) & $(5)$ & $(6)$ & (7) \\
\hline$\Delta \log \left(\mathrm{CPI}_{\mathrm{t}}\right)$ & $\begin{array}{c}.02 \\
(.10) \\
\end{array}$ & $\begin{array}{c}.44 \\
(.09)\end{array}$ & $\begin{array}{c}-.02 \\
(.09) \\
\end{array}$ & $\begin{array}{c}.35 \\
(.06)\end{array}$ & $\begin{array}{c}.03 \\
(.05) \\
\end{array}$ & $\begin{array}{c}.57 \\
(.07)\end{array}$ & $\begin{array}{c}-.004 \\
(.034) \\
\end{array}$ \\
\hline Unemp $_{\mathrm{t}}$ & $\begin{array}{c}-.021 \\
(.003) \\
\end{array}$ & $\begin{array}{c}-.015 \\
(.003) \\
\end{array}$ & $\begin{array}{c}-.024 \\
(.004)\end{array}$ & $\begin{array}{c}-.012 \\
(.002)\end{array}$ & $\begin{array}{c}-.027 \\
(.002) \\
\end{array}$ & $\begin{array}{c}-.010 \\
(.002)\end{array}$ & \begin{tabular}{|c}
-.028 \\
$(.002)$ \\
\end{tabular} \\
\hline Prod_growth(HP) & $\begin{array}{l}.21 \\
(.08)\end{array}$ & $\begin{array}{c}.42 \\
(.08)\end{array}$ & $\begin{array}{l}.16 \\
(.05)\end{array}$ & $\begin{array}{c}.62 \\
(.05)\end{array}$ & $\begin{array}{l}.25 \\
(.07)\end{array}$ & $\begin{array}{l}.57 \\
(.07)\end{array}$ & $\begin{array}{l}.57 \\
(.13)\end{array}$ \\
\hline Wage-gap $\mathrm{t}_{\mathrm{t}-1}$ & $\begin{array}{c}-.25 \\
(.06) \\
\end{array}$ & $\begin{array}{c}-.28 \\
(.08) \\
\end{array}$ & $\begin{array}{c}-.23 \\
(.08) \\
\end{array}$ & $\begin{array}{c}-.35 \\
(.05) \\
\end{array}$ & \begin{tabular}{|c|}
-.27 \\
$(.06)$ \\
\end{tabular} & $\begin{array}{c}-.37 \\
(.06) \\
\end{array}$ & \begin{tabular}{|c|}
-.42 \\
$(.10)$ \\
\end{tabular} \\
\hline$\Delta \log \left(\mathrm{CPI}_{\mathrm{t}}\right) *$ Deflation & & $\begin{array}{l}-1.81 \\
(.22) \\
\end{array}$ & & $\begin{array}{c}-.47 \\
(.06) \\
\end{array}$ & & \begin{tabular}{|c|}
-.64 \\
$(.05)$ \\
\end{tabular} & \\
\hline Wage-gap $_{\mathrm{t}-1} *$ Deflation & & & $\begin{array}{c}.09 \\
(.15) \\
\end{array}$ & $\begin{array}{c}.21 \\
(.06) \\
\end{array}$ & & & $\begin{array}{c}.35 \\
(.10) \\
\end{array}$ \\
\hline Unemp $_{t}{ }^{*}$ Deflation & & & & & \begin{tabular}{|c|}
.003 \\
$(.001)$ \\
\end{tabular} & $\begin{array}{c}.0009 \\
(.0008) \\
\end{array}$ & $\begin{array}{c}.006 \\
(.001) \\
\end{array}$ \\
\hline Constant & $\begin{array}{c}.12 \\
(.02) \\
\end{array}$ & $\begin{array}{c}.065 \\
(.013) \\
\end{array}$ & $\begin{array}{c}.13 \\
(.02) \\
\end{array}$ & $\begin{array}{c}.057 \\
(.008) \\
\end{array}$ & \begin{tabular}{|c|}
.13 \\
$(.01)$ \\
\end{tabular} & $\begin{array}{c}.036 \\
(.009) \\
\end{array}$ & $\begin{array}{c}.12 \\
(.01) \\
\end{array}$ \\
\hline
\end{tabular}

\footnotetext{
18 The results presented in Tables IV.2 and IV.3 correspond to equations where there is no dummy variable for the intercept. Adding such a dummy does alters some coefficient estimates, especially in Table IV.3, but does not modify our main conclusions. The corresponding results can be obtained from the authors on request. It is worth noticing in this context that the deflation dummy and $\Delta \log \left(\mathrm{CPI}_{\mathrm{t}}\right)$ are highly collinear in our sample (the correlation coefficient is -.85).
} 
Taken together the estimates corroborate those obtained from the VAR model in section III, where found that the contribution of foreign shock in the variance decomposition of wages was relatively small at short horizons. Our structural interpretation in terms of the wage equation estimated here explains this by the limited direct effect of foreign prices in the wage equation and by the significant lags involved in the transmission via the real wage gap and the output gap/unemployment rate.

\section{IV.3. The IS equation.}

We have seen that inflation depends on wage developments and that wage developments depend on domestic demand conditions. It remains to explore the determinants of domestic demand. To this end we estimate a conventional IS-type equation of the form

$y_{t}=\beta_{0}+\beta_{1} y_{t}^{f}+\beta_{2} \log \left(\right.$ reer $\left._{t}\right)+\beta_{3} r_{r}+\beta_{4} y_{t-1}$

where $y_{t}\left(y_{t}^{f}\right)$ stands for a measure of domestic (foreign) demand conditions, reer for $_{t}$ the real exchange rate (measured such that an increase represents a real appreciation), and $r_{t}$ for the real interest rate. In the empirical application the domestic and foreign demand conditions are measured by estimated output gaps based on Hong Kong real GDP and real GDP of the main trading partners. Two interest rate series were used, the US 3month T-Bill rate and the 3-month Hibor rate. In view of the fixed exchange rate the two follow each other quite closely, but at times there have been significant differences, notably in the second half of 1997 and in 1998. To calculate real interest rates, the year on year percentage change in the CPI was used as the inflation measure. Estimations were made using GMM with four lags of the dependent and each of the independent variables as instruments. As in the previous sections, we used quarterly spanning 1984:1 to 2003:2. The results are presented in Table IV.4, column (1) when the US T-Bill rate is used and column (3) when it is replaced by the local 3-month Hibor rate.

Not surprisingly, the external output gap has a strong influence on the Hong Kong business cycle. The coefficients imply a close to one-for-one effect. The coefficient on the real exchange rate is negative as expected. A real appreciation of ten percentage points will according to the point estimates reduce the output gap by about four tenth of one percentage point. To put this in perspective, the output gap in Hong Kong declined about 5 percentage points between the first quarter of 1997 and the first quarter of 1998 . During the same time the Hong Kong dollar appreciated in real terms by $12 \%$. Hence the estimates in the table imply that of the 5 percentage point drop in the output gap only 0.5 can be explained by the real appreciation. ${ }^{19}$

\footnotetext{
${ }^{19}$ These calculations do not take into account the lagged effects implied by the presence of the lagged output gap among the regressors. Taking this into account, the long run effect of the real appreciation would be 1.1 and 1.2 percentage points respectively if we use only the IS equation in the calculations. However, the change in the output gap would elicit changes in both wages and prices as we have seen in the previous sections, so the full impact would have to be calculated using these equations as well.
} 
The effects of interest rate changes are negative and significantly different from zero. The estimates using the HK rate are quite close to those using the US rate as expected given the high correlation between them. The differences will concern mainly the interpretation of the downturn after the 1997 Asian crises that we will comment on further below. The size of the coefficients imply that an increase in the real interest rate by one percentage point will decrease the output gap by 0.32 percentage points in the current quarter ( 0.23 percentage point using the Hong Kong interest rate). The real Hibor rate increased by approximately 3 percentage points between the third quarter of 1997 and the third quarter of 1998. The estimates imply that the direct impact of this was a decline in the output gap of about 0.7 of a percentage point.

Columns (2) and (4) in the table are introduced to test whether the transmission mechanism of foreign shocks has changed in the deflation period following the Asia crisis. As in the previous section we interact one of the independent variables with our deflation dummy. We have limited the possible interaction terms to the effect of the foreign output gap. The main consequence is a striking increase in the impact of the external output gap in the post 1997 period. ${ }^{20}$ For example, when the Hong Kong interest rate is used (column 4) the response coefficient is 1.84 in the deflation period as opposed to .50 before. Absent a theoretical explanation of this change in response we simply offer this result as an intriguing empirical regularity at this stage.

\begin{tabular}{|c|c|c|c|c|}
\hline \multicolumn{5}{|c|}{ Table IV.4: The IS equation } \\
\hline & (1) & (2) & (3) & (4) \\
\hline $\mathrm{y}^{\text {gap-world }}(\mathrm{t})$ & $\begin{array}{c}.97 \\
(.12) \\
\end{array}$ & $\begin{array}{c}.65 \\
(.07) \\
\end{array}$ & $\begin{array}{c}.84 \\
(.10) \\
\end{array}$ & $\begin{array}{c}.50 \\
(.08) \\
\end{array}$ \\
\hline $\log [\operatorname{reer}(\mathrm{t})]$ & $\begin{array}{c}-.044 \\
(.007)\end{array}$ & $\begin{array}{l}-.028 \\
(.003)\end{array}$ & $\begin{array}{c}-.038 \\
(.005)\end{array}$ & $\begin{array}{c}-.025 \\
(.003)\end{array}$ \\
\hline $\mathrm{i}^{\mathrm{US}}(\mathrm{t})$ & $\begin{array}{c}-.0032 \\
(.0006) \\
\end{array}$ & $\begin{array}{c}-.0021 \\
(.0004) \\
\end{array}$ & & \\
\hline $\mathrm{i}^{\mathrm{HK}}(\mathrm{t})$ & & & $\begin{array}{c}-.0023 \\
(.0004) \\
\end{array}$ & $\begin{array}{c}-.0020 \\
(.0002) \\
\end{array}$ \\
\hline$y^{\mathrm{gap}}(\mathrm{t}-1)$ & $\begin{array}{c}.52 \\
(.04)\end{array}$ & $\begin{array}{c}.62 \\
(.03)\end{array}$ & $\begin{array}{c}.61 \\
(.03)\end{array}$ & $\begin{array}{c}.64 \\
(.02)\end{array}$ \\
\hline $\mathrm{y}^{\text {gap-world }}(\mathrm{t}) *$ deflation $(\mathrm{t})$ & & $\begin{array}{r}1.27 \\
(.17) \\
\end{array}$ & & $\begin{array}{r}1.34 \\
(.13) \\
\end{array}$ \\
\hline Constant & $\begin{array}{c}.21 \\
(.04)\end{array}$ & $\begin{array}{c}.14 \\
(.01)\end{array}$ & $\begin{array}{l}.18 \\
(.02)\end{array}$ & $\begin{array}{c}.12 \\
(.01)\end{array}$ \\
\hline
\end{tabular}

We end the discussion of the IS equation by commenting briefly on the residuals from the IS equations in the sharp decline in economic activity during 1998 and 1999 and the pick-up in 2000. Figure IV.1 contains our measure of the output gap together with the residuals from three of the equations represented in Table IV.4 (the numbering of the shocks in the figure corresponds to the columns in the table). Consider the decline in the

${ }^{20}$ Adding a dummy for the intercept as well does not alter this conclusion. 
output gap from approximately zero at the end of 1997 to just over $-5 \%$ in the third quarter of 1998. Of this decline the equation in column 1 can explain all but 1.5 percentage points. If we include the effect of the increase in the real Hibor rate we only have one half of one percent unaccounted for. If we in addition allow for the structural change in the transmission of the external output gap, we can account for the entire drop in the domestic output gap during this period. In fact, during the entire period from the end of 1997 to the end of 1999 where our measure of the output gap was negative, it is only one quarter, 1998:3, which is not well accounted for by the equation if we rely on the versions represented in column 4 of Table IV.4. In fact, the model underpredicts the output gap somewhat in 1999.

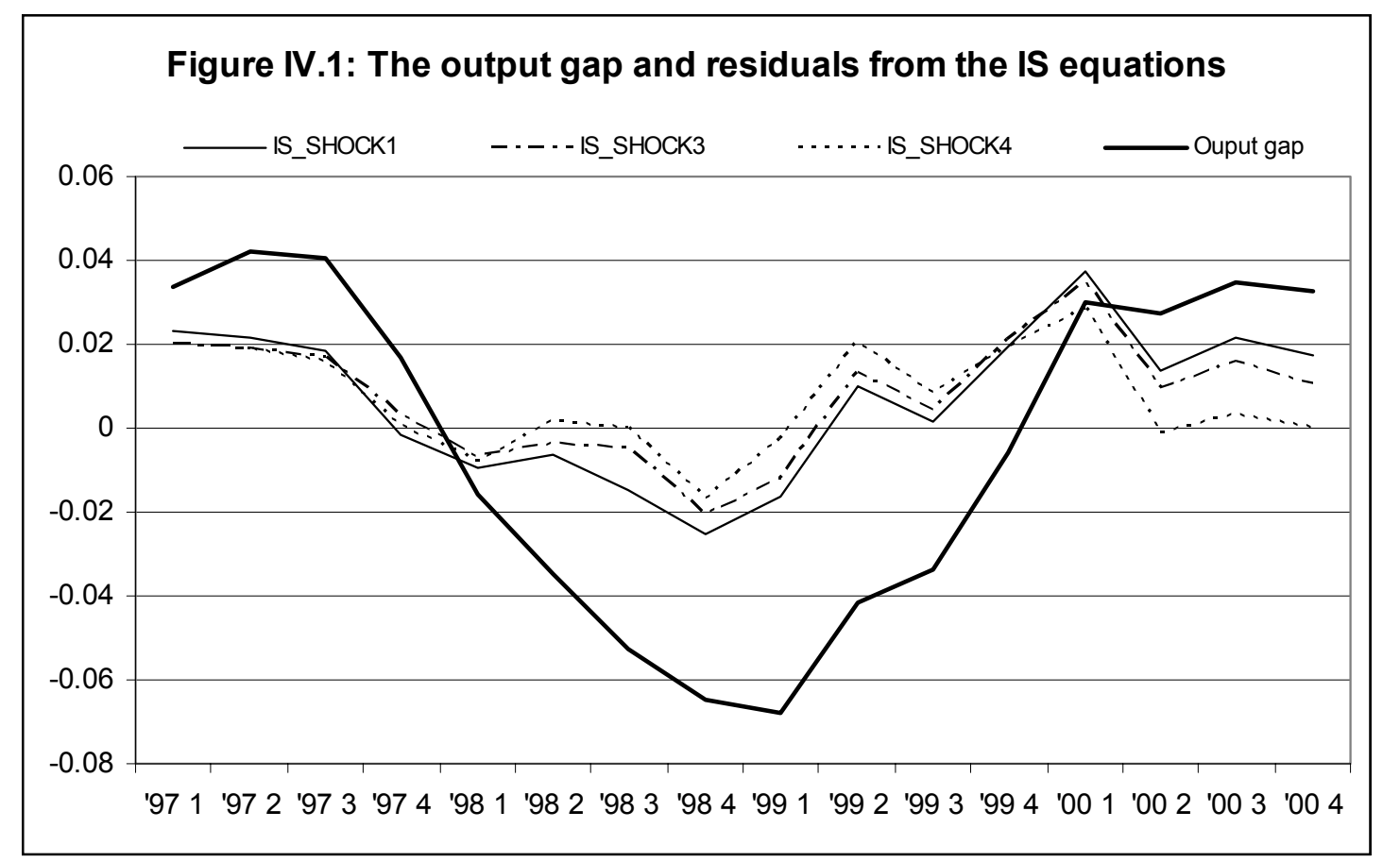

\section{IV.4 Okun's Law in Hong Kong}

The last piece in the price-wage-output-unemployment puzzle is the relationship between the output gap and the unemployment rate. The equation we estimate is a version of Okun's Law which takes into account the effect of real-wage and realexchange-rate movements. Specifically,

$\boldsymbol{u}_{\boldsymbol{t}}=\gamma_{0}+\gamma_{1} \boldsymbol{y}_{\boldsymbol{t}}^{\text {gap }}+\gamma_{2}\left[\ln \left(\frac{\boldsymbol{W}}{\boldsymbol{P}}\right)_{t-1}-\omega_{t}\right]+\gamma_{3} \log \left(\right.$ reer $\left._{t}\right)+\gamma_{4} \boldsymbol{u}_{t-1}$ 
The unemployment rate is assumed to depend on the output gap, the excess real wage we used earlier in the wage equation, and the real exchange rate. Including the real exchange rate in addition to the real wage gap can be justified if the demand for labor depends on the composition of aggregate demand in the economy, and if this composition is likely to be influenced by the real exchange rate. The results are presented in Table IV.5. All the included variables are highly significant. A reduction of in the output gap by 5 percentage point increases the unemployment rate by a little over one half of a percentage point in the short run and by just over $2 \%$ in the long run taking account of the adjustment implied by the coefficient on the lagged dependent variable. Excessive growth in the real wage rate leads to unemployment. For example, the increase in the real wage gap of 12 percentage points between the beginning of 1997 and the end of 2002 would account for an increase in the unemployment rate of $4 \%$ taking account of the all the lagged adjustment implied by the presence of the lagged dependent variable in the regression. Finally the results show that a real appreciation increases the Hong Kong unemployment rate controlling for aggregate demand and the wage gap. This could be due to a reduction in demand for labor as overall demand switches from external demand to domestic demand.

\begin{tabular}{|l|c|}
\hline \multicolumn{2}{|c|}{ Table IV.5: Okun's Law } \\
\hline $\mathrm{y}^{\text {gap }}(\mathrm{t})$ & -11.13 \\
& $(1.03)$ \\
\hline wage $^{\text {gap }}(\mathrm{t})$ & 8.53 \\
& $(1.42)$ \\
\hline $\log [\operatorname{reer}(\mathrm{t})]$ & 2.27 \\
& $(.26)$ \\
\hline $\mathrm{u}(\mathrm{t}-1)$ & 0.74 \\
& $(.03)$ \\
\hline constant & -9.35 \\
& $(1.10)$ \\
\hline
\end{tabular}

\section{IV5. Discussion}

We would like to draw attention to four aspects of the empirical results that we have obtained. First, the inflation process in Hong Kong can be interpreted in terms of the New Keynesian Phillips Curve (NKPC) paradigm if we allow for a significant role of import prices in the marginal cost measure. This is necessary to generate the kind of dependence of local prices on external prices that we observe in the data. Second, in the standard form of the NKPC where only wages are included in the marginal cost would imply a weak influence of foreign prices because our wage equation shows that the adjustment of wages to prices in general is relatively slow. The process operates partly through an error correction mechanism where excessive (relative to productivity) real wages put downward pressure on wage inflation. We found evidence that the wage adjustment process has been slower during the deflation period aggravating the unemployment problem. Even in Hong Kong where flexibility is notorious, there seems to be some difficulty to have negative wage growth. 
The third point we want to highlight is that real economic activity as measured by the output gap is highly dependent on the external business cycle. Although we did find evidence of a significant competitiveness effect through the real exchange rate, this effect is quantitatively small relative to the direct external demand effect, at least as an explanation of the size of real economic fluctuations in Hong Kong. Here as well we found some evidence of a structural change after 1997, in that the economy seems to have become more sensitive to external shocks in this period compared to before.

Finally we have shown that it is possible to interpret movements in unemployment by a version of Okun's law provided it is augmented to allow for the effect of both excessive real wage growth and variations in the real exchange rate.

The structural interpretation we have given complement the VAR results obtained in section III. We can understand the strong and relatively rapid foreign effects on prices we found in the VAR model by their direct impact on domestic price setting. We can also explain the weaker short-run reaction of wages and unemployment by the sluggishness of the wage adjustment process and its implication for employment.

\section{Understanding Hong Kong's deflation.}

The evidence we have presented implies that the deflation in Hong Kong since 1997 can be understood using a conventional macroeconomic framework. The picture that emerges is one where foreign shocks constitute the basic underlying shocks (Section III.2), and adjustment processes in domestic wages and prices determine the details of the transmission mechanism. Both the VAR results and the estimates of the open economy New Keynesian Phillips curve indicate that the decline in local nominal prices owes much to declining prices of imported intermediate goods. Our results imply that the negative output gap and the increase in unemployment also have their origin in foreign shocks, but the domestic wage adjustment process constitutes an important contributing factor.

In our view most of the deflation can thus be explained as the normal, albeit painful, adjustment of the Hong Kong economy to a deflationary external environment. There are however some interesting caveats to this point of view. We have seen that allowing for changes in structural parameters in the post 1998 period helps the explanatory power of several of the equations we have estimated. For example, wage adjustment seems to be slower during this period than before, and the Hong Kong economy seems now to be more sensitive to external demand fluctuations than it was previously. Are these consequences of the deflation itself, or are they due to the change in the political status that took place at this time? Perhaps some of the apparent structural changes are related to changes in trade patterns or the microeconomic structure of the economy, which are not captured in our macroeconomic approach. Further research may help to shed light on these issues. Such research might also investigate that the changes observed in Hong Kong are present also in other countries in the region.

If the deflation in Hong Kong has its principal origin abroad, the recovery must also be externally driven. Domestic wage and price adjustments will over time restore competitiveness, but this is likely to be a drawn-out process. Within the strict confines of 
the set of equations we have estimated, a depreciation of the Hong Kong dollar would also be beneficial as it could lead to increases in external prices and reverse the nominal deflation process. However, this will do little to increase real external demand in view of the low real exchange rate elasticities in the IS equation. Furthermore, changing the exchange rate peg is such a far-reaching change in economic policy that the equations we have estimated are likely to be altered significantly. The Lucas' critique would surely apply in such a circumstance.

\section{References.}

Balakrishnan, R., López-Salido, J. D. (2002). "Understanding UK Inflation: the Role of Openness", Bank of England Working Paper No. 164.

Blanchard, O.J., Katz, L. (1999). "Wage Dynamics: Reconciling Theory and Evidence". American Economic Review 89, 69-74.

Calvo, G. A. (1983). "Staggered Prices in a Utility Maximising Framework". Journal of Monetary Economics 12, 383-398.

Gagnon, E., Khan, H. (2001). "New Phillips Curve with Alternative Marginal Cost Measures for Canada, the United States, and the Euro Area". Bank of Canada Working Paper 2001-25.

Galí, J., Gertler, M. (1999). "Inflation dynamics: A Structural Econometric Analysis". Journal of Monetary Economics 44, 195-222.

Galí, J., Gertler, M., Lopez-Salido, D. (2001). "European Inflation Dynamics”. European Economic Review 45 (7), 1237-70.

Galí, J., Gertler, M., López-Salido, J. D. (2003). "Robustness of the Estimates of the Hybrid New Keynesian Phillips Curve". CEPR Conference, Berlin, June 5- 7.

Galí, J., López-Salido, J. D. (2000). “A New Phillips Curve for Spain”. Banco de Espana, mimeo. Paper prepared for the XIII Simposio de Moneda y Crédito on 'El Análisis Económico frente a los problemas de la Sociedad Moderna', Madrid, November.

Gali, J., Monacelli, T. (2000). "Monetary Policy and Exchange Rate Volatility in a Small Open Economy”. Boston College Working Paper No. 438.

Genberg, H. (2003). "Foreign Versus Domestic Factors as Sources of Macroeconomic Fluctuations in Hong Kong”. HKIMR Working Paper No. 17.

Genberg, H., Pauwels, L. (2003). "Inflation in Hong Kong, SAR - In Search for a Transmission Mechanism”. HKIMR Working Paper No. 1.

Genberg, H., Pauwels, L. (2004). “An Open Economy New Keynesian Phillips Curve: Evidence from Hong Kong". Pacific Economic Review, this issue.

Genberg, H., Salemi, M., Swoboda, A. (1987). "The Relative Importance of Foreign and Domestic Disturbances for Aggregate Fluctuations in the Open Economy, Switzerland 1964-81." Journal of Monetary Economics 19, (1), 45-67.

IMF(2002). "People's Republic of China --- Hong Kong Special Administrative Region: Selected Issues", Country Report No. 02/99, May.

Lindé, J. (2000). "Estimating New-Keynesian Phillips Curves: A Full Information Maximum Likelihood Approach". Sveriges Riksbank Working Paper Series No.129.

Newey, W., West, K. (1987). “A Simple Positive Semi-Definite, Heteroskedasticity and Autocorrelation Consistent Covariance Matrix". Econometrica 55, 703-708. 
Peng, Wensheng, Cheung, Lillian and Cynthia Leung (2001), "The Property Market and the Macro-Economy", Quarterly Bulletin 5/2001, Hong Kong SAR: Hong Kong Monetary Authority, p.40-49.

Roberts, J. M. (2001). "How Well Does the New Keynesian Sticky-Price Model Fit the Data?" Federal Reserve Board Working Papers, February.

Rudd, J., Whelan, K. (2001). "New Tests of the New-Keynesian Phillips Curve". Federal Reserve Board Working Papers, Division of Research and Statistics, June.

Stock, J., Wright, J., Yogo, M. (2002). "A Survey of Weak Instruments and Weak Identification in Generalized Method of Moments". Journal of Business \& Economics Statistics 20, (4), 518-529.

Taylor, J. B. (1980) "Aggregate Dynamics and Staggered Contracts," Journal of Political Economy 88, 1-23. 